\title{
Practices and policies of health promotion in Brazil: context, challenges, and potentialities
}

\author{
Marcos Bagrichevsky ${ }^{*}$ (1)
}

Thinking about health and disease, consistently interpreting its multiple meanings - as phenomena connected to the social, economic, cultural events of everyday life - represents a challenging task, above all, from an interdisciplinary perspective. This is a permanent commitment of the multi-professional health teams that make up the "first level of care" in the Brazilian Unified Health System (SUS), also called the "gateway to the system" or "Primary Health Care (PHC)" 1

The context of the peripheral territories in Brazil in which the PHC teams work is the feature of places almost always riddled with inequities, violence, and historically outside the reach of resolutive social policies. For obvious reasons, this situation needs to be considered, problematized and included in the continuum of "expanded therapeutic projects" in health that are aimed at the comprehensive and equitable care of people/ populations linked to such territories ${ }^{2}$.

The incorporation of this set of premises by PHC professionals (including family and community doctors) is one of the SUS guidelines. The regular adoption of this practice in the work process of the PHC teams has, for some time, shown to have significant implications in addressing local and regional health problems ${ }^{2-4}$.

The implantation of SUS in the early 1990s leveraged the transformation of the health care model in the country. The development of a culture of 'other practices' in PHC, in tune with the dimension of the 'extended look' on the health-illness process, has come to give an increasing role to health promotion as a field inducing 'differentiated ways' of thinking and producing care in the daily experiences of services ${ }^{5}$.

Critical currents of Brazilian thinkers and sanitarians have credited health promotion, the potential to become a valuable counterpoint to the hegemonic biomedical model of assistance and its medicalizing logic. Almeida-Filho ${ }^{6}$, for example, postulates that this is one of the great challenges to be faced by professionals and managers who work in the public health field.

For the services to be able to obtain health promotion actions appropriate to our conjuncture of micro-realities, it is necessary to attend and articulate two essential tasks in the PHC routine:

(i) to reflect on the ethical-political assumptions that guide such practices; and

(ii) to consider the need to reconfigure traditional pedagogical enterprises, which are still dominant in the 'health education' activities used along with population groups ${ }^{7}$.

The critical perspective of health promotion in Brazil ${ }^{5-7}$ calls for both actions, programs, and policies (inside and outside the health sector) to improve the structural conditions of society ${ }^{8,9}$, and for opening up to the context of 'non-medicalized' life that requires a continuous production of strategies to value and enable listening, welcoming, and the subjects' singularities ${ }^{10}$. And both dimensions are not mutually exclusive, it is good to say. On the contrary, they converge and add up towards a politicizing project, socially relevant, but without the naive pretension of becoming the 'salvation' for all the 'evils' that affect our collectives.

Concerning this second facet, demedicalization and respect for human subjectivities, it is essential that the repertoire of devices used by PHC professionals contemplate/accept the aspects that give existential meaning to people, families, as the primacy of comprehensive health care processes concern and are intended for them. Their priorities and life aspirations must not be discarded or 'objectified', even in the face of extreme illness situations ${ }^{11}$. Sector managers also play a strategic role in this context and need to be committed to the same guidelines, developing them daily, pari passu with services.

\footnotetext{
'Universidade Regional de Blumenau - Blumenau (SC), Brazil.

*Corresponding author: marcos_bagrichevsky@yahoo.com.br

Conflicts of interest: the authors declare there is no conflicts of interest. Funding: none.
} 
The challenges facing the Brazilian social and health scenario are complex and numerous. They require from the field of health promotion (and those who pass through it) the construction of 'operational' paths that privilege, at the same time, a sensitive and equitable view of reality. Equally important is the need to institutionalize these initiatives, which need to gain public visibility and be more prestigious/recognized in the services, as well as the professionals who plan and conduct these processes ${ }^{11,12}$.

In this sense, I raise a question addressed to those who occupy positions in the formulation/management of health policies in our country: why not grant the health workers responsible for health promotion groups/projects ${ }^{13}$ in the territories of $\mathrm{PHC}$, the same "cash prizes"* formally allocated to health teams that obtain a reduction in epidemiological indicators of morbidity and mortality? In general terms, the structured proposals for health promotion are long-lasting, obtain long-term adherence from group/project goers, promote bonding, create spaces for listening, sociability, and politicization in communities. In other words, there are plenty of concrete and plausible reasons for them to be recognized and 'made official' by the administrative bodies of the health secretariats of Brazilian municipalities, as powerful and resolving actions. Despite being characterized as an old claim of professionals who work with health promotion in PHC, the question raised here also expresses a recurring dilemma from which managers cannot escape: how to define adequate choices (conceptual and methodological) for coping with different health problems present in the communities, wherein in the balance of 'objectivity versus subjectivity' only the first one mostly guides decision-making?

But, despite the existence of ethical-political aspects such as the one here highlighted and problematized briefly in the text (and which deserve to be discussed in depth!), it is worth saying that in the last decade and a half we have accumulated countless successful health promotion experiences conducted by health teams, across the country ${ }^{13-15}$. The record of its growing presence in the PHC territories indicates two aspects: (i) the extent to which health promotion interventions can contribute to the well-being of local populations and mitigate the difficulties that they face and prevent full, continuous care; and

(ii) that we have reached an interesting status towards the consolidation of a recommended health care model and that we want for SUS ${ }^{11,12}$.

The counter-hegemonic health promotion approaches shared in the PHC territories have as their primary guideline the ethical dimension of the subjects 'and collectivities' lives. They bring with them concepts that are essential to health care that presuppose the ability to dialogue between different knowledge and practices. Such understanding demands much more from the actors in the sector than the use of tools to map health problems; they expect an interdisciplinary interpretative analysis that also seeks to consider the complexity of the health-disease process and all the modes of subjectification that it mobilizes; that detaches from more immediate meanings (those traditionally expected by the biomedical model), and it is capable of expressing a more detailed, sensitive, and deep condition that each situation examined requires.

The final balance I make of these contemporary perspectives in Brazil points out dense and well-trodden paths. These are recent transformations; it is true but noteworthy! The permanent debate around the National Health Promotion Policy (NHPP) 5 evoked by different actors in society and the resulting repercussions illustrate my point of view: first published in 2006, NHPP has already undergone its second review in 2014, exhibiting since then, expressive textual changes in content and number ${ }^{5}$. Some of them have even 'officially' recognized the role of modes of subjectification in the composition of therapeutic care projects - a concern that did not exist in the first version of the NHPP $(2006)^{5}$. Indeed, there is still much to do, what to fight for, in policies and services. Nonetheless, even in the face of the recent Brazilian situation that inspires a certain amount of pragmatism, we have marked advances that deserve our recognition!

\section{REFERENCES}

1. Gomes KDO, Cotta RMM, Araújo RMA, Cherchiglia ML, Martins TDCP. Atenção Primária à Saúde--a "menina dos olhos" do SUS: sobre as representações sociais dos protagonistas do Sistema Único de Saúde. Cien Saude Colet. 2011;16(Suppl 1):881-92. Portuguese. https://doi.org/10.1590/s141381232011000700020
2. Barra SAR, Oliveira LML. User embracement in the Primary Healthcare System: a device to trigger changes in the organization of the work process? Rev Atenc Prim Saude. 2012 [cited on Mar. 28, 2018];15(2):126-38. Available from: https://pesquisa.bvsalud.org/portal/resource/pt/ lil-676092

*At Brazilian Unified Health System (SUS), since 2011 there has been a government initiative called "Program for Improving Access and Quality in Primary Care" (PMAQ-AB, the initials into Portuguese) that pays cash bonuses to PHC health professionals/teams who achieve 'productivity goals' regarding improving epidemiological indicators recommended by the Ministry of Health. The recurring criticism is that there is nothing similar proposed to 'value likewise' the professionals who work continuously with "health promotion actions/groups" and/ or with the subjective dimensions of care and who are also known to be successful through respective 'expanded therapeutic projects. 
3. Aquino R, Oliveira NF, Barreto ML. Impact of the family health program on infant mortality in Brazilian municipalities. Am J Public Health. 2009;99(1):87-93. https://doi.org/10.2105/ AJPH.2007.127480

4. Figueiredo KMS, Gonçalves GAA, Batista HMT, Akerman M, Pinheiro WR, Nascimento VB. Actions of primary health care professionals to reduce maternal mortality in the Brazilian Northeast. Int J Equity Health. 2018;17(1):104. https://doi. org/10.1186/s12939-018-0817-x

5. Silva PFA, Baptista TWF. The National Health Promotion Policy: text and context of a policy. Saude Debate. 2015;39(Suppl 1): 91-104. https://doi.org/10.5935/0103-1104.2015S005327

6. Almeida-Filho N.O que é saúde? Rio de Janeiro: Fiocruz; 2011.

7. Czeresnia D. O conceito de saúde e a diferença entre prevenção e promoção. In: Czeresnia D, Freitas CM, Eds. Promoção da saúde: conceitos, reflexões, tendências, Rio de Janeiro: Fiocruz; 2017. p. 39-54.

8. Marmot M. Brazil: rapid progress and the challenge of inequality. Int J Equity Health. 2016;15(1):177. https://doi.org/10.1186/ s12939-016-0465-y

9. Akerman M, Moyses ST, Franco de Sá RMP, Mendes R, Nogueira $J A D$, Zancan $L$, et al. Democracy and health promotion. Health Promot Int. 2019;34(suppl 1):i1-3. https://doi.org/10.1093/ heapro/daz016
10. Czeresnia D, Maciel EMGS, Oviedo RAM. Os sentidos da saúde e da doença. Rio de Janeiro: Fiocruz; 2016.

11. Ferreira Neto Jl, Araujo JNG. Management and subjectivity in SUS: facing dilemmas in neoliberal times. Psicol Soc. 2014;26(3):67584. https://doi.org/10.1590/S0102-71822014000300016

12. Mendes R, Pezzato LM, Sacardo DP. Research and intervention in the promotion of health: methodological challenges of researching "with". Cien Saude Colet. 2016;21(6):1737-46. https://doi.org/10.1590/141381232015216.07392016

13. Santos LM, Da Ros MA, Crepaldi MA, Ramos LR. Grupos de promoção à saúde no desenvolvimento da autonomia, condições de vida e saúde. Rev Saude Publica. 2006;40(2):34652. https://doi.org/10.1590/s0034-89102006000200024

14. Pinto MB, Lara KS. Health promotion in the territory: strengths and challenges of local projects. Esc Anna Nery. 2019;23(1):e20180282. https://doi.org/10.1590/21779465-EAN-2018-0282

15. Heidemann ITSB, Cypriano CDC, Gastaldo D, Jackson S, Rocha CG, Fagundes E. Estudo comparativo de práticas de promoção da saúde na atenção primária em Florianópolis, Santa Catarina, Brasil e Toronto, Ontário, Canadá. Cad Saude Publica. 2018;34(4):e00214516. https://doi.org/10.1590/0102$311 \times 00214516$ 